\title{
Decreased cellular and humoral anti-infective factors in the breast secretions of lactating mothers with lepromatous leprosy
}

\author{
K SAHA,* V SHARMA ${ }^{\dagger} \&$ M A SIDDIQUI ${ }^{\ddagger}$ \\ *Department of Bacteriology, Govind Ballabh Pant Hospital, \\ $\dagger$ Department of Microbiology, Maulana Azad Medical College, \\ $\$$ Leprosy Home, Municipal Corporation of Delhi, New \\ Delhi-1 10032, India
}

Received for publication 12 April 1981

\begin{abstract}
Summary. Breast secretions from 28 healthy lactating women and 12 lepromatous mothers feeding their children for a varying period ( 2 days$2 \frac{1}{2}$ years) were studied for the total and differential cell counts and immunoglobulin concentrations. It was observed that the total leucocyte count in the milk of the lepromatous mothers was low and also the macrophage count was significantly decreased. The mean secretory immunoglobulin-A level was significantly decreased in the colostrum as well as in the mature milk of the lepromatous mothers as compared to those from the healthy mothers. Acid-fast bacilli could be detected in 9 of the 12 leprosy patients' breast secretions by employing a new technique of coprecipitation of bacteria by $4 \%$ polyethylene glycol. The immunologic implications of these findings have been discussed.
\end{abstract}

\section{Introduction}

There is considerable evidence to show that the breast feeding is biologically superior to any other form of infant feeding. ${ }^{1,2}$ Lactating lepromatous leprosy patients are economically underprivileged and are known to excrete leprosy bacilli in their breast secretions. ${ }^{3}$ Since breast milk is very often the major source of nutrition to the babies born to these patients, they tend to prolong breast feeding until the child is 2 to 3 years of age. The immunologic profile of the colostrum and mature milk from the lepromatous mothers has not been adequately known. In the present study the cellular composition and immunoglobulin levels in the breast secretions collected from the lactating leprosy 
patients were estimated and compared with those in the healthy mothers from a similar socio-economic background.

\section{Materials and methods}

Samples of breast secretions were collected from 12 lepromatous leprosy patients (aged from 19 to 30 years) breast feeding their children for a varying period ( 2 days $-2^{1 / 2}$ years). The diagnosis of leprosy was established in these patients by clinical features, histopathology, bacilloscopy and lepromin test (armadillo-derived lepromin, WHO Geneva). ${ }^{4}$ The disease spectrum varied from borderline lepromatous (BL) in 7 cases to polar lepromatous in 5 cases. One patient in each group developed erythema nodosum leprosum (ENL) during early postpartum period. Twenty-eight healthy mothers (aged from 21 to 30 years) nursing their infants for a varying time ( 2 days $-1 \frac{1}{2}$ years) were studied as age- and parity-matched controls.

Five $\mathrm{ml}$ of colostrum (breast secretion during first $72 \mathrm{~h}$ ) or milk was collected by manual expression. A known volume of each sample was centrifuged in a siliconized glassware within $1 / 2$ hour of its collection at $500 \mathrm{~g}$ for $15 \mathrm{~min}$. The fat collected on the top was removed. The supernatant was separated and kept frozen at $-20^{\circ} \mathrm{C}$ and used for the quantitation of immunoglobulins. The volume of the centrifuged deposit consisting of the cells was noted and resuspended in standard white-blood-cell diluting fluid and the total number of cells were counted in an improved Neubar's chamber. The differential cell count was performed after staining the cell deposits by Giemsa technique and various cells were expressed as a percentage after counting all the cells in the smear.

Smears made from the centrifuged cellular deposit were also stained for acid-fast bacilli. ${ }^{3}$ In addition, equal volumes of milk and $8 \%$ polyethylene glycol in distilled water (PEG, molecular weight 6000, BDH, England) were mixed and allowed to stand for an hour at room temperature. The mixture was then centrifuged at $500 \mathrm{~g}$ for $15 \mathrm{~min}$ and the precipitate obtained was washed thrice with 4\% PEG. A smear made from this washed precipitate was stained as above for acid-fast bacilli. This method of smear preparation has been found by this laboratory to be better in the detection of bacillaemia in the patients with lepromatous leprosy. ${ }^{5}$ This PEG-precipitated material was then cultured on Lowenstein Jensen medium for growth of mycobacteria.

Levels of immunoglobulin $\mathrm{A}, \mathrm{G}$ and $\mathrm{M}$ were measured by single radial immunodiffusion technique ${ }^{6}$ using commercially obtained monospecific antisera against secretory $\operatorname{Ig} \mathrm{A}, \operatorname{IgM}$ and $\operatorname{IgG}$ and their reference standards (Meloy Laboratories, USA). Colostral IgA standard, kindly donated by $\mathrm{Dr}$ R A Thompson (Birmingham, England), was used for estimation of immunoglobulin A. 
The observations were statistically evaluated and paired $t$-tests of significance were done to compare the data.

\section{Results}

Colostral secretions were collected from 2 lepromatous mothers, one having ENL reaction and 14 matched controls while mature milk was obtained from 10 patients (one having ENL) and another 14 healthy nursing mothers. Figure 1 shows the scatter of the total cell counts and immunoglobulin levels in the colostrum samples obtained from normal and lepromatous mothers. No overlap was seen between the total cell counts and IgA levels of the 2 groups.

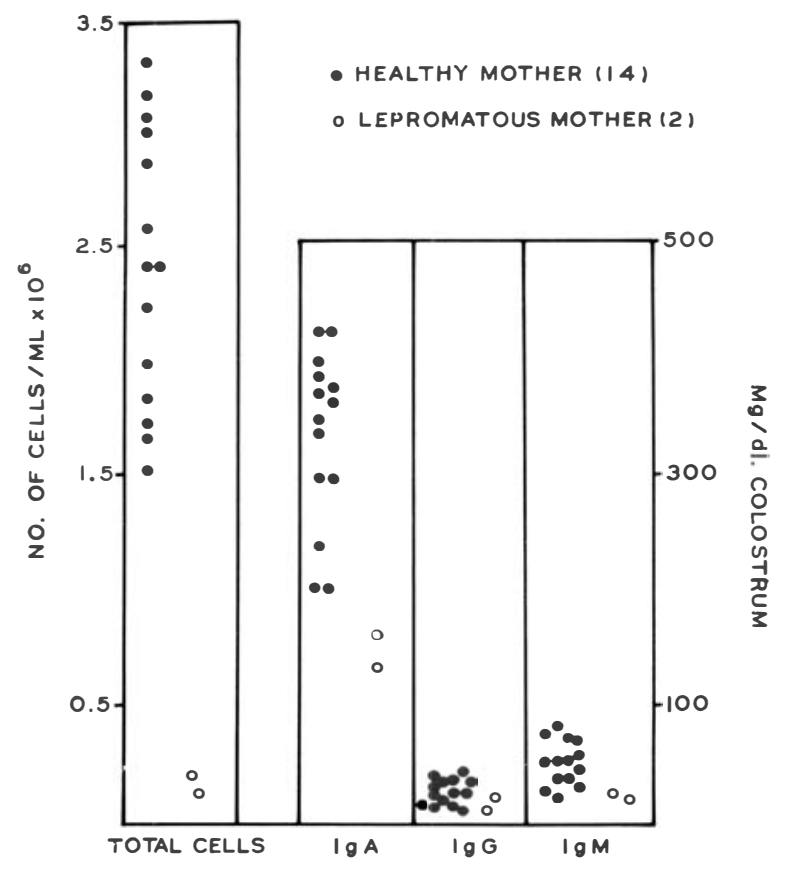

Figure 1. Scattergram showing total cell counts and immunoglobulin levels in the colostrum samples obtained from 14 healthy and 2 lepromatous mothers. No overlap was seen between the cell counts and IgA levels of the 2 groups.

Tables 1 and 2 describe the total and differential cell counts and immunoglobulins $\mathrm{A}, \mathrm{G}$ and $\mathrm{M}$ concentrations in colostrum and milk respectively. It was observed that while the cells seen in the breast secretions of healthy mothers and lepromatous patients were morphologically similar (Fig. 2), the mean total cell count and percentage of macrophages were remarkably lower in the latter than in the former group. The average cell counts were higher in colostrum 
Table 1. Total and differential cell counts and immunoglobulin concentrations in the colostrum of the lactating lepromatous patients and healthy controls

\begin{tabular}{|c|c|c|c|c|c|c|c|c|}
\hline \multicolumn{2}{|c|}{ Lactating mothers } & \multirow{2}{*}{$\begin{array}{l}\text { Total cell count } \\
\text { per ml } \\
\text { mean } \pm \mathrm{SD} \\
\text { (range) }\end{array}$} & \multicolumn{3}{|c|}{$\begin{array}{c}\text { Mean differential count (\%) } \\
\text { (range) }\end{array}$} & \multicolumn{3}{|c|}{$\begin{array}{c}\text { Immunoglobulin level } \\
(\mathrm{mg} / \mathrm{dl}) \\
\text { mean } \pm \mathrm{SD} \\
\text { (range) }\end{array}$} \\
\hline Group & Number & & Polymorph & Lymphocyte & Macrophage & A & G & M \\
\hline Healthy & 14 & $\begin{array}{c}24,50,000 \pm 4,85,667 \\
(15,50,000-32,00,000)\end{array}$ & $\begin{array}{c}28 \\
(10-42)\end{array}$ & $\begin{array}{c}22 \\
(2-42)\end{array}$ & $\begin{array}{c}50 \\
(25-75)\end{array}$ & $\begin{array}{c}340 \pm 92 \\
(205-425)\end{array}$ & $\begin{array}{r}25 \pm 12 \\
(10-40)\end{array}$ & $\begin{array}{l}50 \pm 29 \\
(20-85)\end{array}$ \\
\hline $\begin{array}{l}\text { Lepromatous } \\
\text { leprosy }\end{array}$ & $2 *$ & $\begin{array}{l}1,55,000 \\
(1,50,000 \& 1,60,000)\end{array}$ & $\begin{array}{c}20 \\
(16 \& 24)\end{array}$ & $\begin{array}{c}68 \\
(64 \& 72)\end{array}$ & $\begin{array}{c}12 \\
(12 \& 12)\end{array}$ & $\begin{array}{l}150 \\
(157.5 \& 162.5)\end{array}$ & $\begin{array}{l}15.5 \\
(10 \& 21)\end{array}$ & $\begin{array}{l}22.5 \\
(20 \& 25)\end{array}$ \\
\hline
\end{tabular}

*Both patients showed acid-fast bacilli in milk both by direct as well as PEG-precipitated smear examination. 


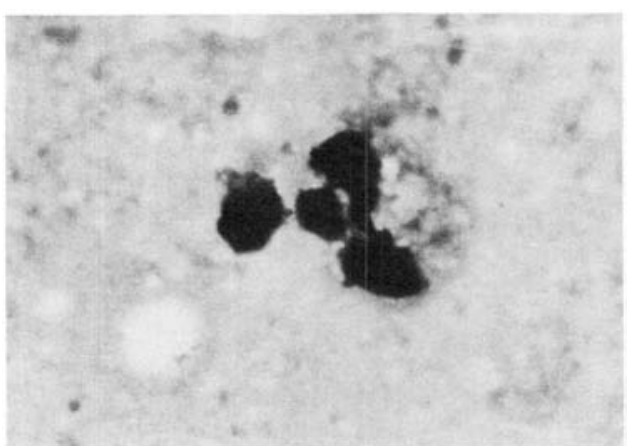

(a)

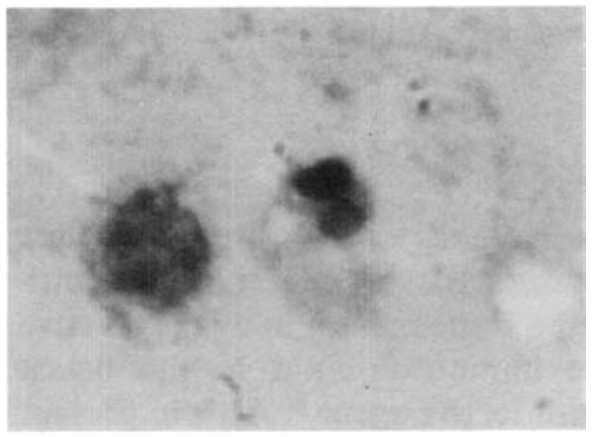

(c)

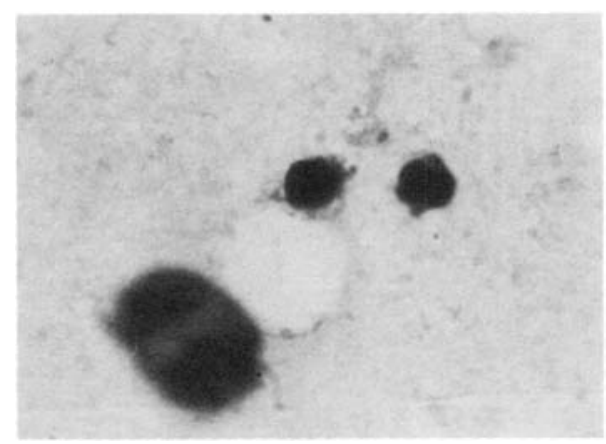

(b)

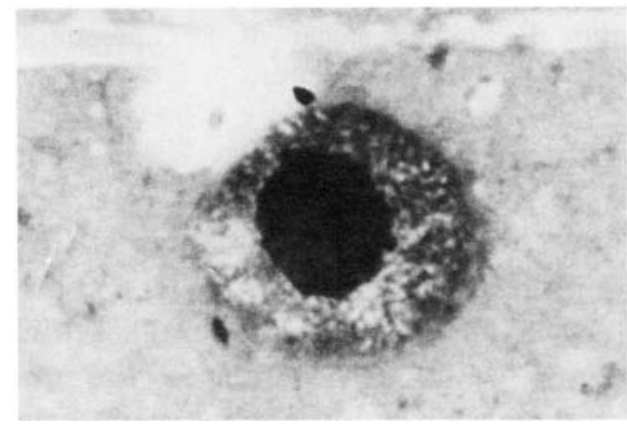

(d)

Figure 2. Various types of cells in colostrum of a normal healthy mother. (a) - Four-lobed polymorphonuclear leucocyte; (b) - Two lymphocytes; (c) - Macrophage (left) and a bilobed polymorphonuclear leucocyte (right); (d) - Colostral corpuscle (macrophage).

than that in mature milk. Also, in all cases, there was a higher concentration of immunoglobulin A in colostrum than in milk samples. There was a significant difference in the mean level of IgA in the colostrum and milk of the leprotic mothers as compared to the healthy mothers (Tables $1 \& 2$ ). On the other hand, no significant changes were observed in the levels of immunoglobulins $\mathrm{G}$ and $\mathrm{M}$ in breast secretions of the leprosy patients and age-parity-matched controls. Table 3 analysed the effect of the duration of lactation on the total cell counts and the profile of immunoglobulin levels in the mature milk samples obtained from both healthy as well as lepromatous mothers. As the period of breast feeding increased there was a concomitant fall of the cellular content as well as the immunoglobulin concentrations of the milk samples from both the groups. Interestingly, there was a steeper fall of the cellular contents in the milk of the healthy mothers than in the lepromatous mothers.

Excretion of Mycobacterium leprae was demonstrated in the milk of 9 out of 12 leprosy patients. Figure 3 depicts a stained smear of PEG-precipitated breast-milk sample showing an acid-fast bacillus. No acid-fast bacilli could be grown on culture in Lowenstein Jensen medium. 


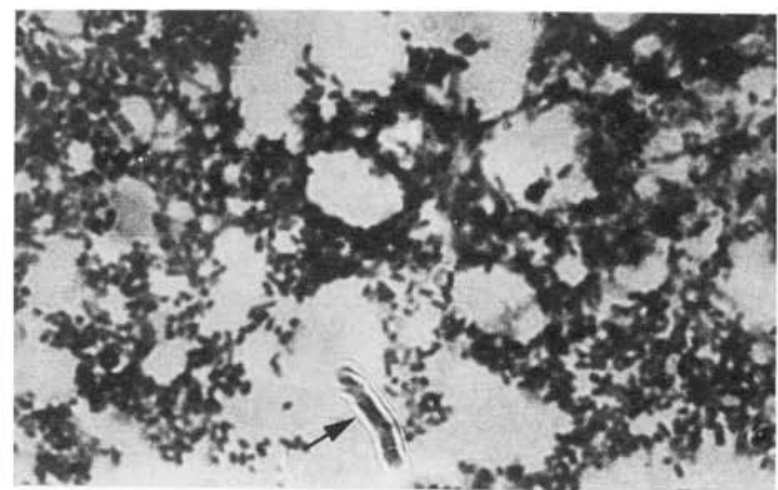

Figure 3. Stained smear of PEG-precipitated breast milk from a lepromatous mother showing an acid-fast bacillus.

\section{Discussion}

There are several studies to suggest that breast milk has a protective role against infection in the infant..$^{7-9}$ It is now recognized that there are several antiinfective factors in human milk which may be responsible for this protective action. ${ }^{1}$ Milk IgA which is the dominant immunoglobulin in the breast secretion is probably the most important anti-infective agent. ${ }^{10}$ This important immunoglobulin was found to be significantly low in the colostrum as well as in the mature milk of the lepromatous mothers compared with the healthy mothers. It is now known that the gut shares with other mucosal surfaces, an extensive immunological system that operates somewhat differently and separately from the systemic immune mechanisms. ${ }^{10}$ The profile of the immunoglobulin classes in the latter system shows increased levels in the lepromatous patients, ${ }^{11}$ while in the former system, as seen in the tears, ${ }^{12}$ salivary secretions ${ }^{13}$ and intestinal aspirates, ${ }^{14}$ there appears a decrease in the IgA concentration. This observed dissociation between these 2 immunological compartments is remarkable. The $\operatorname{IgA}$ immunocytes are said to arise from the gut-associated lymphoid tissue and home-in on the mammary glands and also to other mucosal surfaces. ${ }^{10,15}$ This homing is influenced by the presence of antigen ${ }^{10}$ and hormones. ${ }^{16}$ Acid-fast bacilli have been seen in breast secretions ${ }^{3}$ and also in the intestinal aspirates. ${ }^{14}$ It is, therefore possible that these specialized committed IgA immunocytes may home 'to see' the similar antigen $(M$. leprae or its products) in the breast. Cooper et al. ${ }^{17}$ have shown that IgAantibody production is T-cell dependent. These thymus-derived lymphocytes are functionally impaired in lepromatous patients. ${ }^{11}$ For the induction of immunoglobulin-A synthesis by the antigen-sensitive B cell, it is believed ${ }^{18}$ that 2 signals are required. Signal 1 is generated after binding the antigen to the $\mathrm{B}$-cell antigen receptor site. This is followed by signal 2 generated as a result of $\mathrm{T}$-cell recognition of foreign determinants on the $\mathrm{B}$-cell membrane. This 
Table 2. Total and differential cell counts and immunoglobulin concentrations in the mature milk of the lactating lepromatous patients and healthy controls

\begin{tabular}{|c|c|c|c|c|c|c|c|c|}
\hline \multicolumn{2}{|c|}{ Lactating mothers } & \multirow{2}{*}{$\begin{array}{l}\text { Total cell count } \\
\text { per ml } \\
\text { mean } \pm \mathrm{SD} \\
\text { (range) }\end{array}$} & \multicolumn{3}{|c|}{$\begin{array}{c}\text { Mean differential count }(\%) \\
\text { (range) }\end{array}$} & \multicolumn{3}{|c|}{$\begin{array}{l}\text { Immunoglobulin level } \\
(\mathrm{mg} / \mathrm{dl}) \\
\text { mean } \pm \mathrm{SD} \\
\text { (range) }\end{array}$} \\
\hline Group & No. & & Polymorph & Lymphocyte & Macrophage & A & G & M \\
\hline Healthy & 14 & $\begin{array}{l}16,25,000 \pm 2,54,667 \\
(7,25,000-25,25,000)\end{array}$ & $\begin{array}{c}25 \\
(10-40)\end{array}$ & $\begin{array}{c}35 \\
(20-25)\end{array}$ & $\begin{array}{c}40 \\
(20-60)\end{array}$ & $\begin{array}{l}102 \pm 25 \\
(50-150)\end{array}$ & $\begin{array}{l}14 \pm 5 \\
(5-22.5)\end{array}$ & $\begin{array}{l}6 \pm 2.4 \\
(2.5-10)\end{array}$ \\
\hline $\begin{array}{l}\text { Lepromatous } \\
\text { leprosy }\end{array}$ & $10 *$ & $\begin{array}{r}1,27,334 \pm 37,794 \\
(74,700-2,00,000)\end{array}$ & $\begin{array}{c}15 \\
(0-30)\end{array}$ & $\begin{array}{c}80 \\
(70-90)\end{array}$ & $\begin{array}{c}5 \\
(0-10)\end{array}$ & $\begin{array}{l}40 \pm 7.5 \\
(25-50)\end{array}$ & $\begin{array}{l}10 \pm 4.5 \\
(5-15)\end{array}$ & $\begin{array}{l}8.5 \pm 2 \\
(5.5-12)\end{array}$ \\
\hline $\begin{array}{c}\text { Statistical eval } \\
t \text { value } \\
p \text { value }\end{array}$ & & $\begin{aligned} & 22.43 \\
< & 0.001\end{aligned}$ & & & & $\begin{array}{l}8.7 \\
<0.001\end{array}$ & & \\
\hline
\end{tabular}

* Seven of the 10 patients showed acid-fast bacilli in PEG precipitate only and not by direct smear examination. 


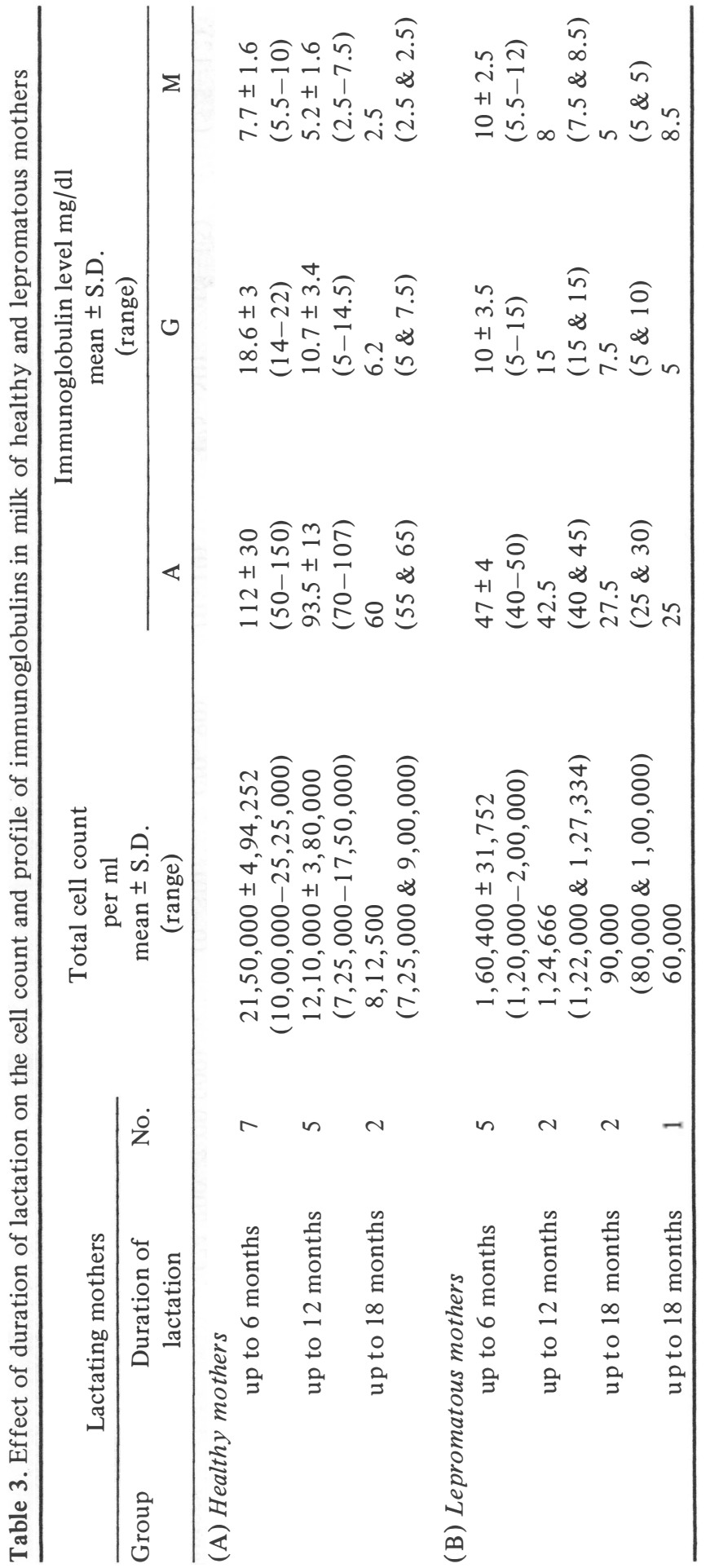


sophisticated 2-signal model thus proposes that a single antigenic signal would induce a state of tolerance unless the cell concomitantly received a second (mitogenic) signal from the $\mathrm{T}$ cell. ${ }^{19}$ The significant decrease in levels of the $\operatorname{Ig} \mathrm{A}$ in lepromatous mothers as reported in the present study supports this notion. The specificity of $\operatorname{IgA}$ antibody in the lepromatous leprosy mothers, however, remains to be demonstrated.

The anti-microbial activity of the breast milk is not only mediated by antibodies but also by the lymphoid cells including neutrophils and macrophages. ${ }^{10}$ As many as $10^{6}$ cells $/ \mathrm{ml}$ of colostrum are regularly found during the first 2 weeks after delivery while up to $10^{5}$ cells $/ \mathrm{ml}$ may still be detected 6 months after. ${ }^{20}$ The leucocytes and macrophages play an important part in preventing infection in the mammary gland as well as in the infant's gastrointestinal tract. ${ }^{21}$ The observation of a definite drop in the total leucocytic cells and macrophage counts in the breast secretions of the leprosy patients assumes significance in this context. Breast milk is not sterile and may contain bacteria which are mainly harmless. ${ }^{22}$ These bacteria are known to promote a normal bacterial colonization of the gastrointestinal tract and also suppress the invasiveness of certain pathogenic micro-organisms. ${ }^{1}$

However, the effect of the ingestion of lepra bacilli by the infant of the lepromatous mothers for a prolonged period is not yet shown. A serious consequence of taking $M$. leprae or its products by these unfortunate babies may be an induction of specific immunologic tolerance ${ }^{23,24}$ by the generation of suppressor T cells. ${ }^{25}$

\section{References}

${ }^{1}$ Hanson LA, Winberg J. Breast milk and defence against infection in the newborn. Arch Dis Child, 1972; 47: 845.

2 Pittard III WB. Breasst milk immunology. Am J Dis Child, 1979; 133: 83.

3 Bryceson A, Pfaltzgraff RE. In: Leprosy. Edinburgh: Churchill Livingstone, 2nd edn. $1979 ; 34,128$.

4 Ridley DS, Jopling WH. Classification of leprosy according to immunity: A five group system. Int J Lepr. 1966; 34: 255.

${ }^{5}$ Chakraborty AK, Saha K, Prakash N. Detection of $M$. leprae in immune complex enriched fraction after precipitation with polyethylene glycol of sera from lepromatous patients. Abstract, Fourth International Congress of Immunology, Paris, 1980, Theme No. 18, Workshop No. 18.2.

${ }^{6}$ Mancini G, Carbonara AC, Heremans JP. Immunochemical quantitation of antigens by single radial immunodiffusion. Immunochem, 1965; 2: 235.

${ }^{7}$ Hanson LA, Johansson BG. Immunological studies of milk. In: McKenzie H, ed. Milk Proteins, Chemistry and Molecular Biology. New York: Academic Press, 1970. Vol. I.

8 Reddy V, Bhaskaram C, Raghuramulu N, Jagdeesan V. Antimicrobial factors in human milk. Acta Paediatr Scand, 1977; 66: 229.

${ }^{9}$ Narayanan I, Prakash K, Gujral VV. The value of human milk in the high risk low-birthweight-infant. J. Pediatr, 1981; 99: 496. 
10 Ciba Foundation Symposium 42, The advantages of breast milk. In: Acute Diarrhoea in childhood, Symposium held at Ciba Foundation, London. Amsterdam: Elsevier Scientific Co, 1976; 131, 145, 173.

11 Bullock WE. Leprosy: A model of Immunological Perturbation in chronic infection. $J$ Inf Dis, 1978; 137: 341 .

12 Saha K, Sarin GS, Chakraborty AK, Sen DK. Ocular immunoglobulins in lepromatous leprosy. Int J Lepr, 1977; 45: 338.

13 Saha K, Chakraborty AK. Immunologic aspects of lepromatous leprosy as related to the immunoglobulin of the external secretions. Salivary Immunoglobulins. Int J Lepr, 1977; 45: 261.

14 Saha K, Agarwal SK, Misra RC. Gut associated IgA deficiency in lepromatous leprosy. Scand J Immunol, 1978; 8: 397.

15 Tomasi Jr. TB, Larson L, Challacombe S, McNabb P. Mucosal immunity - The origin and migration patterns of cells in the secretory system. J Allergy Clin Immunol, 1979; 65: 12.

16 Weisz-Carrington P, Roux ME, McWilliams M, Phillips JM, Lamm ME. Hormonal induction of the secretory immune system in the mammary gland. Proc Natl Acad Sci, 1978; 75: 2928.

17 Cooper MD, Kincade PW, Bockman DE, Lawton AR. Origin, distribution and differentiation of IgA producing cells. Adv Exp Med Biol, 1973; 45: 13.

18 Kagnoff MF. Induction and Paralysis - A conceptual framework from which to examine the intestinal immune system. Gastroenterol, 1974;66: 1240.

19 Dresser DW. Tolerance induction as a model for cell differentiation. Brit Med Bull, 1976; 32: 147 .

20 Ogra SS, Ogra PL. Immunologic aspects of human colostrum and milk. II. Characteristics of lymphocyte reactivity and distribution of E-rosette forming cells at different times after onset of lactation. Paediatrics, 1978; 92: 550.

21 Smith CW, Goldman AS. The cells of human colostrum. I. In-vitro studies of morphology and functions. Pediatr Res, 1968; 2: 103.

22 Wyatt RC, Matta LJ. Bacteria in colostrum and milk of Guatemalan Indian women. $J$ Trop Pediatr, 1969; 15: 159.

23 David MF. Induction of hyporesponsiveness to particulate antigen by feeding: The sequence of immunologic response to fed antigen. J Allergy Clin Immunol, 1979; 64: 164.

${ }^{24}$ Chatterjee BR. Attempt to induce immune tolerance to M. leprae in mice. Lepr India $1981 ; 53: 34$.

${ }^{25}$ Reinherz EL, Schlossman SF. Regulation of the immune response inducer and suppressor T-lymphocyte subsets in human beings. New Engl Jour Med, 1980; 303: 370. 